\title{
KNOWLEDGE MANAGEMENT IN INTELLIGENT ORGANIZATIONS
}

doi: $\quad 10.2478 /$ czoto-2019-0128

Date of submission of the article to the Editor: 28/11/2018

Date of acceptance of the article by the Editor: 21/01/2019

\author{
Beata Skowron-Grabowska ${ }^{1}$ - orcid id: 0000-0003-4845-4717 \\ Tomasz Szczepanik ${ }^{1}$ - orcid id: 0000-0003-4932-8229 \\ Petr Besta ${ }^{3}$ \\ ${ }^{1}$ Czestochowa University of Technology Poland, beata.skowron.grabowska@wz.pcz.pl \\ ${ }^{2}$ Technical University of Ostrava Czech Republic
}

\begin{abstract}
The aim of the paper was to present the specificity of knowledge management in courier companies as an example of intelligent organizations. Knowledge management is a modern concept that emphasizes using the most valuable resources of enterprises such as employees and it offers conditions for development of knowledge, sharing it, and thinking creatively. The paper presents courier companies as an example of intelligent organizations that use knowledge management in the implementation of courier services. The article presents the results of a survey that identified the use of knowledge in courier companies and analysed the factors that made the surveyed companies become intelligent organizations. The solutions implemented in enterprises that influenced the emergence of a competitive advantage were evaluated. Furthermore, the benefits achieved by the companies surveyed due to knowledge management and the growth of their intelligence were analysed.
\end{abstract}

Keywords: courier companies, intelligent organization, courier services, management, knowledge management

\section{INTRODUCTION}

The concept of an intelligent organization is a relatively new field of modern enterprise management, which was established and has been developing in connection with the ever-growing competition, high pace of technological development and dynamically changing management conditions. With changes and emerging challenges resulting from the processes of transformation of the modern economy, the term knowledgebased economy (KBE) has become of critical importance to enterprises. This concept means an economy based on the production, distribution and use of knowledge and information in all areas of activities. In conditions of the knowledge-based economy, high development rates and a favourable market position can be generated only by intelligent organizations which are able to learn and use knowledge in an efficient and effective manner. An intelligent organization means an entity that is better able to obtain, process and use information than others. 
With the access to new technologies and the quality of services offered on the market, courier companies must constantly compete to maintain their competitive position by creating knowledge and managing it as intelligent organizations in order to improve the courier services offered.

\section{INTELLIGENT ORGANIZATION MANAGEMENT}

Development of enterprises, sectors and markets has driven the necessity to develop management methods and implementation of new concepts to support management (Pettinger, 2007). This is aimed at adjustment to the needs of service providers such as courier companies in order for them to function efficiently and effectively (NowickaSkowron, 2000).

The idea ofintelligent organization results from numerous concepts of management sciences, including in particular: organization as an information system, the concept of learning organization (Anttila and Jussila, 2018), knowledge management, or intellectual capital of an organization. A wide range of theoretical foundations translates into a multitude of approaches and definitions, which results in the lack of a single, universally accepted definition.

The intelligent organization is composed of all participants working on the achievement of relevant knowledge (outcomes) at all levels, in groups or individually. Such an organization gives its employees full freedom of action within their competences, with the minimum control of other people (Łęgowik-Świącik, 2016). A key element of such an organization is trust in the competencies of the employees (Skowron-Grabowska and Mesjasz-Lech, 2016) assuming, for example, willingness to cooperate, bringing new solutions, innovations (Kmieciak et al., 2012), and creative approach to problem-solving (Mikuła, 2006) .

The feature that distinguishes intelligent enterprises is above all the control of acquired skills through experience used to create new knowledge. (Koohang et al., 2018) Knowledge comes from experience, generated from various contacts within the company, as well as interactions outside the company: with suppliers, customers, and local community (Zimniewicz, 2009). Such knowledge is not always used to solve a specific problem immediately after it is acquired, but it is certainly worth preserving and using in the future. ( Ciszárik-Kocsir, 2017). Experience, which is constantly expanded and enriched, allows for constructive assessment of the enterprise operations, new concept or experiments.

An intelligent organization is characterized by specific capabilities that distinguish it from other organizations (Schwaninger, 2009):

- adaptability to the changing situations;

- ability to influence and shape the environment;

- ability to find new strategic domains (service-market arrangements) in their external environment, and thus to adapt resources immediately according to this domain;

- ability to contribute positively to the development of their environment within the framework of the concept of sustainable development (so-called socioecological strategies).

Courier companies are organizations with a high degree of adaptability to the changing conditions and customer needs. Competitiveness in the sector forces the search for opportunities arising from the environment, with courier companies being able to quickly adapt their resources to prepare and deliver courier services. 


\section{KNOWLEDGE AND KNOWLEDGE MANAGEMENT IN INTELLIGENT ORGANIZATIONS}

Modern economies are constantly evolving towards knowledge-based economies, and knowledge is becoming an important category of the organizational resources, with particular focus on intelligent organizations. Knowledge is of key and strategic character to enterprises, resulting, on the one hand, from its more difficult imitation and substitution with respect to material resources, and on the other hand, from its higher flexibility, i.e. usefulness for creation or improving various elements of the company's services (Sopińska, 2008). Knowledge perceived as a company's resource category is closely related to processes of data and information processing. Data are the basic components that create knowledge, but they are meaningless without a specific context. (Grondys, 2017). Data can become information only if they are selected, grouped, compared, combined and compiled in the appropriate context and evaluated. Furthermore, information with the appropriate structure enabling its use in a specific field of activity forms knowledge (Probst et al., 2002). The resource offered by knowledge, is characterized by the following features (Olszewska, 2001):

- inexhaustibility - knowledge does not decrease as it is used, and its value even increases.

- simultaneity - means that knowledge can be used in many locations by different people or organizations simultaneously.

- non-linearity - manifested by different effects obtained by various enterprises by using the same amount of knowledge.

These features indicate that knowledge is the most important and at the same time very specific resource and has an advantage over other organizational resources (Rzemieniak, 2016). As a strategic resource of an enterprise, knowledge should be constantly identified, measured, acquired, developed, used and protected, meaning that it should be subject to individual management processes.

The problem of knowledge management has been widely discussed in the literature. Most often, it is defined as (Perechuda, 2005):

- Creating and utilizing knowledge in order to improve the efficiency of the organization's activities.

- Management of knowledge, information and experience the organization has, consisting in their collection, creation and storage, sharing and use, aimed at ensuring development of the organization based on existing resources.

- Creating the effective work environment and knowledge transfer system within the organization to ensure activation to share knowledge.

The use of knowledge in order to improve the operations of the organization and to stimulate creation and sharing knowledge has also been emphasized.

The application of knowledge management in a courier company is aimed to strengthen the company's position with respect to competitors through the process of identification, acquisition and management of knowledge supported by four factors: strategy and leadership, organizational culture, technology and measurement system (Kari, 2018). Activities within each factor are equally important, and their simultaneous proper fulfilment represents a key to the achievement of the desired effects. 


\section{KNOWLEDGE MANAGEMENT IN COURIER COMPANIES AS AN EXAMPLE OF INTELLIGENT ORGANIZATIONS}

The pace of changes in the world economy is proportional to the technological progress. Recent years have seen a rapid development of new technologies and growing global competition. (Gábor, 2017). The form of intelligent organization has evolved as a result of dynamic changes in the environment of organizations, which used knowledge management to become successful. Courier companies competing in the dynamically developing courier services market have to respond to the changing customer needs and services offered by competitors to minimize risks (Dohn et al., 2017).

Courier companies are specialized providers of logistics services, with their activities performed in the field of supply, transport and distribution (Jeszka, 2009). "Logistics services include commercially provided forwarding, transportation and warehousing services" (Jeszka, 2009), also including courier services (Solakivi, 2001). Courier services can be defined as non-universal services consisting in providing commercial services of accelerated transport and timely delivery (Act, 2003). These services are often dedicated, tailored to the expectations and high requirements of customers. Management of courier services in intelligent organizations such as courier companies represents a solution based on knowledge management (Durst and Evangelista, 2018), and the use of innovativeness, technology and human resources, in the form of the potential of qualified and specialized employees.

The research covered 57 courier companies from the Czech Republic and Poland. Research was carried out among managers by using survey questionnaire The aim of the study was to identify the characteristics of intelligent organizations in courier companies and determine factors that make these companies become intelligent organizations. The focus was also on identification and assessment of solutions implemented in enterprises, affecting the emergence of competitive advantage and determination of the benefits experienced by the courier companies due to increased intelligence. The features most often indicated by courier companies regarded as characteristics of intelligent organizations are presented in Table 1.

Table 1

The most frequent features of intelligent organizations indicated in the courier companies surveyed

\begin{tabular}{|l|c|}
\hline \multicolumn{1}{|c|}{ Features of intelligent organization } & $\begin{array}{l}\text { \% of respondents indicating a } \\
\text { feature as the most important }\end{array}$ \\
\hline $\begin{array}{l}\text { Internal legal regulations, such as: staff development } \\
\text { plan, promotion principles, periodic evaluation }\end{array}$ & 47.3 \\
\hline $\begin{array}{l}\text { Capability to generate, codify, store and transfer } \\
\text { knowledge }\end{array}$ & 70.2 \\
\hline Capability to learn at individual and group levels & 64.9 \\
\hline $\begin{array}{l}\text { Employment of high-class experts, i.e. knowledge } \\
\text { workers and using their talents }\end{array}$ & 71.9 \\
\hline Company development strategy & 68.4 \\
\hline $\begin{array}{l}\text { Capability to adapt and apply new knowledge (innovation, } \\
\text { technology) to courier services }\end{array}$ & 80.7 \\
\hline $\begin{array}{l}\text { Capability to develop formal and permanent } \\
\text { relationships with other market participants }\end{array}$ & 57.9 \\
\hline
\end{tabular}

Source: elaboration based on the author's study. 
The survey revealed that the vast majority of the companies surveyed (80.7\%) most often indicated that their main feature in the area ofintelligent organizations was capability to adapt and apply new knowledge in the form of innovations and technology. The other features distinguished by the entities were: employing highclass experts such as knowledge workers and using their talents $(71.9 \%$ of respondents), the capability to generate, codify, store and transfer knowledge $(70.2 \%)$ and having a company development strategy (68.4\%), although only $40 \%$ companies had a formal strategy. The relatively important features indicated by the companies surveyed in the area of intelligent organization were the capability to learn at individual and group levels (64.9\% of respondents) and the capability to develop permanent formal relationships with other market participants (57.9\% of respondents). The smallest percentage of indications was found in the case of having internal legal regulations concerning human resource management, which included staff development plans, principles of promotion, and periodic evaluation (47.3\%). On average, one company indicated 5 possible features defining intelligent organizations. Furthermore, the companies also indicated factors that influenced the fact that they had become intelligent organizations. The results are shown in Table 2.

Table 2.

The most important factors that made the companies surveyed become intelligent organizations

\begin{tabular}{|l|c|}
\hline Factor & $\begin{array}{l}\% \text { of respondents who } \\
\text { indicated a factor as the } \\
\text { most important }\end{array}$ \\
\hline Suggestions from owners & 87.8 \\
\hline The need arising from the business profile & 80.7 \\
\hline Imitation of competitors & 61.4 \\
\hline Suggestions of business partners & 45.6 \\
\hline The emergence of new information technologies & 84.2, \\
\hline
\end{tabular}

Source: elaboration based on the author's study.

The main factor for the vast majority of respondents $(71.9 \%)$ was the suggestions from owners. The next factors that made organizations become intelligent organizations were: the emergence of new information technologies (84.2\%) and the need resulting from the business profile $(80.7 \%$ of respondents). Less important factors according to the respondents were imitating competitors (61.4\%) and suggestions of business partners (45.6\%). On average, one company indicated 4 possible factors that made companies become intelligent organizations. Table 3 contains information on the solutions implemented in the companies surveyed that affected the creation of competitive advantage.

Table 3.

The most frequently indicated solutions implemented in enterprises influencing the emergence of competitive advantage

\begin{tabular}{|l|c|}
\hline Solutions implemented in enterprises & $\begin{array}{l}\text { \% of respondents for whom } \\
\text { the given solution was the } \\
\text { most important }\end{array}$ \\
\hline Cooperation with clients & 75.4 \\
\hline Educating employees or better use of their talents & 73.7 \\
\hline Shaping a good image in contacts with suppliers, & 89.5 \\
\hline
\end{tabular}




\begin{tabular}{|l|c|}
\hline customers, competitors and partners & \\
\hline $\begin{array}{l}\text { Implementation of new knowledge (innovation, technology) } \\
\text { in courier services }\end{array}$ & 84.2 \\
\hline
\end{tabular}

Source: elaboration based on the author's study.

The biggest importance (89.5\% of respondents) was indicated for shaping a good image in contacts with suppliers, customers, competitors and partners. Furthermore, it was important for the respondents $(84.2 \%)$ to implement new knowledge (innovation, technology) in courier services. A significant impact on the creation of competitive advantage was found for cooperation with customers $(75.4 \%)$ and introduction of employee education or better use of their talents (73.7\%). On average, one company studied indicated three possible solutions implemented in enterprises that would influence the emergence of competitive advantage. The benefits the courier companies achieved due to increased intelligence are presented in Table 4.

Table 4.

Most often indicated benefits achieved by the companies surveyed due to the increase in their intelligence

\begin{tabular}{|l|c|}
\hline Benefits achieved by enterprises & $\begin{array}{l}\text { \% of respondents who } \\
\text { indicated a benefit as the } \\
\text { most important }\end{array}$ \\
\hline Raising the position on the market & 56.1 \\
\hline Shaping corporate image and brand recognition & 78.9 \\
\hline Increased quality of courier services & 86 \\
\hline More effective competing to attract customers & 77.2 \\
\hline
\end{tabular}

Source: elaboration based on the author's study.

The main benefit achieved from increasing intelligence indicated by courier companies was improved quality of courier services (86\%). Slightly fewer companies (78.9\%) indicated that an important benefit was the positive shaping of the corporate image and brand recognition and more effective competing for customers (77.2\%). The worst rated benefit of increased intelligence was the increase in the current position on the market $(56.1 \%)$. On average, one company indicated 3 possible benefits they achieved as a result of the increase in their intelligence.

\section{CONCLUSION}

Due to the constant and dynamic development of new technologies and the ubiquitous pressure on quality of services delivered on the market, the courier services sector is a perfect place for implementation and using the concept of an intelligent organization. A survey conducted in courier companies showed that identification of the features of intelligent organizations is at a very high level. As the most important factors that made them become intelligent organizations, courier companies indicated suggestions of owners, followed by the emergence of new information technologies and the needs arising from their business profile, confirming research conducted in companies from other industries (Rumocka, 2016). The companies pointed to the development of a good reputation in contacts with suppliers, customers, competitors and partners as well as the implementation of new knowledge (innovations, technologies) in courier services as the most important solutions implemented in companies that helped them create a competitive advantage. The 
most frequently reported benefits that companies achieved due to increased intelligence were improved quality of courier services. Courier companies show the characteristics of intelligent organizations, because they operate in an industry where the emphasis is placed on the use of modern technologies and an immediate response to changes taking place on the market. Creating and using knowledge is becoming a key factor determining the services offered, relations with clients, and thus functioning on the courier services market. Analysis of study results suggests that the concept of intelligent organization based on knowledge management has a positive effect on management of courier services. Courier companies have to constantly compete to maintain a competitive position by creating knowledge and managing it as intelligent organizations in order to improve the quality of courier services they deliver.

\section{References}

Anttila, J., Jussila, K., 2018. Organizational learning in developing the integrated quality management. Production Engineering Archives, 18, 3-13.

Ciszárik-Kocsir, Á. 2017. What Makes a Successful Project? - The Role of Project Participants According to the Opinion of the Hungarian Companies. Research Reviews of Czestochowa University of Technology, 27(1), 85-95.

Dohn, K., Gaschi-Uciecha, A., Wodarski, K., 2017. Risk management of logistics processes implementation in small and medium-sized enterprises of food industry in Silesian Voivodeship, Zeszyty Naukowe. Organizacja i Zarządzanie Politechnika Śląska, 103, 47.

Durst, S., Evangelista, P., 2018. Logistics knowledge management: state of the art and future perspectives. Special Issue - Logistics knowledge management: state of the art and future perspectives, Accepted 14 Sep 2018, Published online: 16 Oct, 427-434.

Gábor, G., 2017. About Organic Farming and Production in the World and in Hungary. Reviews of Czestochowa University of Technology, 27(1), 118-131.

Govindarajan, V., Gupta, A., Knowledge Management's Social Dimension. Lessons 9.

Grondys, K. 2017. Balanced Scorecard Method in the Outsourcing Decision. Reviews of Czestochowa University of Technology, 27(1), 139-150.

Jeszka, A.M., 2009. Sektor usług logistycznych w teorii i praktyce, Difin, Warszawa, 59.

Karia, N., 2018. Knowledge resources, technology resources and competitive advantage of logistics service providers. Special Issue -- Logistics knowledge management: state of the art and future perspectives, 16 Oct, 451-463.

Kmieciak, R., Michna, A., Męczyńska, A., 2012. Innovativeness, empowerment and IT capability. evidence from SMEs, Emerald Group Publishing Limited, Industrial Management \& Data Systems, 112, 5, 709.

Koohang, A., Paliszkiewicz, J., Gołuchowski, J., Trust, 2018. Knowledge Management, and Organizational Performance: Predictors of Success in Leadership, In: Liebowitz, J., Paliszkiewicz, J., Gołuchowski, J., (Eds). Intuition, Trust, and Analytics; CRC Press, Taylor \& Francis Group, Auerbach Publications: Boca Raton, FL, USA, 83-105.

Łęgowik-Świącik, S., 2016. Identyfikacja i kwantyfikacja modelu decyzyjnego w przedsiębiorstwie inteligentnym. [in:] Zarządzanie przedsiębiorstwem 
inteligentnym. Gregorczyk S., Mierzejweska W. (red.)Wybrane zagadnienia, Oficyna wydawnicza Szkoły Głównej Handlowej w Warszawie, Warszawa, 201.

Mikuła, B., 2006. Organizacje oparte na wiedzy. Wydawnictwo Akademii Ekonomicznej w Krakowie, Kraków, 19.

Nowicka-Skowron, M. 2000. Efektywność systemów logistycznych, PWE, Warszawa 136.

Olszewska, B., 2001. Współczesne uwarunkowania zarządzania strategicznego przedsiębiorstwa. Wydawnictwo AE, Wrocław, 133.

Perechuda, K., 2005. Zarządzanie wiedzą w przedsiębiorstwie. PWN, Warszawa, 1623.

Pettinger, R., 2007. Introduction to Management. 4th ed. New York, NY: Palgrave Macmillan, 53.

Probst, G., Raub, S., Romhard, K., 2002. Zarządzanie wiedzą w organizacji. Oficyna Ekonomiczna, Kraków, 228.

Rumocka, A., 2016. Funkcjonowanie organizacji inteligentnej na przykładzie mikroprzedsiębiorstwa „B+R Studio Analizy Rynku Meblarskiego”. [in:] Zeszyty Naukowe Politehniki Częstochowskiej, Zarządzanie, 23(1),.169-178.

Schwaninger, M., 2009. Intelligent Organizations: Powerful Models for Systemic Management. Springer Verlag, Berlin Heidelberg, Germany.

Skowron-Grabowska, B., Mesjasz-Lech, A., 2016. Konkurencyjne uwarunkowania zarządzania zasobami kadrowymi w przedsiębiorstwach w kontekście dostępu do rynku pracy. Przegląd Organizacji, 10, 22-28.

Solakivi, T., Töyli, J., Engblom, J., Ojala, L., 2011. Logistics outsourcing and company performance of SMEs: Evidence from 223 firms operating in Finland, Strategic Outsourcing: An International Journal, 4(2), 133.

Sopińska, A., 2008: Wiedza - zasób strategiczny współczesnego przedsiębiorstwa. w: Przedsiębiorstwo wobec wyzwań globalnych. Tom 2, (red.) A. Herman, K. Poznańska, Szkoła Główna Handlowa, Warszawa, 67-81.

Ustawa Prawo pocztowe z dnia 12 czerwca 2003 r. Dz.U. Nr 130, poz. 1188

Zimniewicz, K., 2009, Współczesne koncepcje i metody zarządzania. PWE, Warszawa, 84. 